\title{
Evidence for density-dependent mortality in recruitment of a temperate reef fish, cunner Tautogolabrus adspersus, among similar reefs in the vicinity of an anthropogenic disturbance
}

\author{
Paul Nitschke ${ }^{1, *}$, Martha Mather ${ }^{1}$, Francis Juanes ${ }^{2}$ \\ ${ }^{1}$ Massachusetts Cooperative Fish and Wildlife Research Unit, USGS-BRD and ${ }^{2}$ Department of Natural Resources Conservation, \\ University of Massachusetts, Amherst, Massachusetts 01003, USA
}

\begin{abstract}
Determining the factors that regulate recruitment of cunner Tautogolabrus adspersus, a temperate reef fish, can help assess the effect of an anthropogenic disturbance on population abundance. The relative abundance of cunner recruits was tracked over 1 reproductive season via visual counts on line transects across similar habitats at 4 sites across 3 boulder reefs in the vicinity of the Pilgrim Nuclear Power Station (PNPS) in Plymouth, Massachusetts, USA. Habitat characteristics including macroalgae structure, canopy height, rugosity (a measure of structure complexity), temperature, and visibility were measured at each site to assess the influence of these factors on recruit abundance. We assumed that immigration and emigration were not responsible for recruit abundance patterns through time due to the sedentary life history of cunner recruits. We observed differences in recruit abundance over the settlement period among reefs which were likely the result of differences in settlement. However recruitment at the end of the post-settlement period was similar across reefs. Recruit mortality rates among reefs differed in the post-settlement period, with the reef that had the highest density also having the highest mortality rate. Post-settlement mortality rates provided evidence for density-dependent mortality, since habitat and abiotic factors failed to explain the difference in mortality among reefs. Consequently, because of the existence of density-dependent processes in the post-settlement stages, entrainment mortality of the pre-settlement egg and larval stages by the PNPS will have a diminished effect on the local cunner population. An additional assessment of within-reef variability in recruitment also suggests recruitment success is sensitive to small changes in habitat structure which can occur over the recruitment season.
\end{abstract}

KEY WORDS: Settlement - Recruitment - Population regulation · Density-dependent mortality · Disturbance $\cdot$ Habitat $\cdot$ Temperature $\cdot$ Visibility $\cdot$ Cunner Tautogolabrus adspersus

\section{INTRODUCTION}

The difficulties of measuring and comparing larval supply with subsequent recruitment have resulted in a

\footnotetext{
*Present address: National Marine Fisheries Service, Northeast Fisheries Science Center, 166 Water Street, Woods Hole, Massachusetts 02543, USA.

E-mail: paul.nitschke@noaa.gov
}

wide debate on the importance of pre-settlement and post-settlement processes in the regulation of fish population abundance (Sale 1978, Smith 1978, Doherty 1982, 1983, Victor 1983, 1986, Shulman 1984, 1985, Shulman \& Ogden 1987, Connell \& Jones 1991, Hixon 1991, Jones 1991, Hixon \& Beets 1993, Robertson at al. 1993, Doherty \& Fowler 1994, Levin 1996, Caselle 1999, Steele 1999). Numerous studies show that high conspecific or recruit abundance results in compen- 
satory or density-dependent population regulation (Shulman 1984, 1985, Stimson 1990, Forrester 1995, Tupper \& Boutilier 1995a). Other studies show a direct relationship between larval fish abundance and recruitment (Doherty 1982, 1983, Victor 1983, 1986, Milicich et al. 1992, Meekan et al. 1993, Doherty \& Fowler 1994).

This debate has predominantly taken place with studies involving reef fishes. The reason for this is likely due to both the ability to directly observe reef fish using visual census techniques and the relative sedentary nature of reef fish after settlement (Sale 1991). A sedentary juvenile/adult life history characteristic results in regulatory processes occurring at a spatial scale that can be logistically observed via scuba or snorkeling and facilitates experimental manipulation of local population densities.

A better understanding of regulatory processes on population abundance can also be useful for assessing the relative influence of an anthropogenic disturbance on a species. Specifically, evidence of density-dependent processes in the post-settlement stages is informative for evaluating the relative influences of an anthropogenic disturbance. This is particularly true with seawater-cooled power plants, which cause entrainment mortality on the planktonic egg and larval stages for a variety of fish species before regulatory processes can occur in the post-settlement stages (Boreman \& Goodyear 1988, Goodyear 1988). Physical alterations to coastal habitat and diversions in water movement by power plants can also have impacts on resident fish species (Schroeter et al. 1993). In the northeast US, coastal power plants can act as a potential disturbance for a territorial temperate reef fish such as cunner Tautogolabrus adspersus, which often reside in close proximity to power plants. In this study we observe post-settlement processes of cunner in the vicinity of an anthropogenic disturbance, the Pilgrim Nuclear Power Station (PNPS).

The PNPS, a single reactor unit located on the western side of Cape Cod Bay, entrains a relatively large amount of cunner eggs and larvae in comparison with other species (Lawton \& Scherer 1996). An estimated 1.5 and 4 billion cunner eggs, and 9 and 46 million larvae, were entrained in 1994 and 1995, respectively (Lawton \& Scherer 1996). The PNPS also pumps approximately $11.74 \mathrm{~m}^{3} \mathrm{~s}^{-1}$ of seawater with a thermal pollution allowance of up to $17.8^{\circ} \mathrm{C}$ above ambient seawater temperature. Therefore the PNPS is a potential anthropogenic disturbance for the local cunner population.

Cunner is an abundant inshore temperate reef fish in the Gulf of Maine (Bigelow \& Schroeder 1953) and may be an ideal indicator species of localized humaninduced perturbations due to very limited movements during its post-larval life history (Green 1975, Walton et al. 1978, Williams \& Kiceniuk 1987, Mercer et al. 1997). After settlement, cunner recruits (age 0+ fish) have very high site fidelity, often spending the entire first year within a $1 \mathrm{~m}^{2}$ area (Tupper \& Boutilier 1995a, 1997). Therefore observations on decreases in cunner recruit abundance over time at a site can be attributed to mortality. High abundance in inshore waters and territoriality also make cunner a relatively easy species with which to track local abundance through time at a relatively small spatial scale (within $50 \mathrm{~m}^{2}$ ) by using visual census techniques via scuba or snorkeling. Thus cunner possess some desirable characteristics as both an indicator species for assessing impact of an anthropogenic disturbance and as a species with which population regulation processes can be observed.

Herein we investigate the use of trends in juvenile cunner densities over a single reproductive season as a means of determining if evidence for density dependence exists among 3 similar reefs in the vicinity of the PNPS. Several factors have to hold true to make observations of density-dependence effects among reefs possible. First, differences in settlement must produce differences in initial recruit densities once settlement has ended. Initial recruit densities cannot be manipulated for the test of relative PNPS impact to remain valid. Anecdotal observations previous to the study year suggested that differences in settlement do occur among our study reefs. Second, other factors that can influence cunner abundance and mask density-dependent effects need to be taken into account. Habitat has been shown to be a critical factor for determining cunner abundance. For example, structural components of the habitat including macroalgae composition can influence cunner recruitment (Levin 1993, 1994b, Tupper \& Boutilier 1995a). Therefore, in testing density effects, it is essential that habitat does not have differential influences on mortality among reefs. Temperature, wind conditions, and visibility may also be important in influencing cunner abundance and/or activity. Specifically, in this study, we evaluate habitat structure, macroalgal height, rugosity, temperature, visibility, and wind direction at 3 natural boulder reefs to determine the importance of these factors in influencing cunner recruitment. In an additional assessment, we also compare recruitment variability and habitat changes within a reef using 2 sites relatively close to each other $(100 \mathrm{~m})$.

If habitat and abiotic factors fail to explain differences in recruitment and differences in settlement occur among reefs, we can then determine if mortality is related to initial density differences among reef. Recruit abundance was examined in 2 time periods: the settlement and post-settlement periods. First, we 
assess cunner recruit densities over the entire settlement period to determine if relative settlement differs among our study reefs. Second, we assess if mortality rates differ across reefs in the post-settlement period when settlement no longer has an influence on recruit abundance. If differences in settlement produce differences in recruit abundance at the beginning of the post-settlement period, we can then determine if mortality occurred in a density-dependent pattern. Evidence of density-dependent mortality in the post-settlement stages would suggest that the population is regulated after entrainment mortality by the power plant has occurred, which in itself will provide some insight on the relative influence of anthropogenically induced mortality on the pre-settlement stages.

\section{MATERIALS AND METHODS}

Sample sites. We sampled 4 sites across 3 isolated reefs in the vicinity of the PNPS, located on the coastline of Plymouth, Massachusetts, USA. Areas between reefs consisted of sand. The reefs were comprised of glacial boulder deposits with sand/gravel patches interspersed among boulders. Boulders ranged from about 0.5 to $4 \mathrm{~m}$ in diameter and were ubiquitously distributed over each reef. Filamentous (Acrothrix sp., Desmarestia sp.,Ceramium sp., Polysiphonia sp.) and fleshy (Condrus sp., Phyllophora sp.) alga types were the dominant macrophytes that covered boulders. Crustose algae (Hildenbrandia sp., Ralfsia sp., Phymatolithon sp.) covered a relatively small proportion of the boulder surface area (Grocki 1984).

To compare recruitment among-reefs, we sampled single sites on 3 distinct reefs with similar habitat and depth (3 to $3.5 \mathrm{~m}$ mean low water) located within a $2 \mathrm{~km}$ radius of the PNPS (Fig. 1). The first site, discharge (DS), was near the disturbance, approximately $120 \mathrm{~m}$ southeast off the end of the PNPS discharge canal (Fig. 1). The second site, White Horse (WH), was approximately $1.5 \mathrm{~km}$ southeast of the PNPS (Fig. 1), and the third site on the Rocky Point reef (Inner Rocky Point, IRP) was approximately $1 \mathrm{~km}$ northwest of the PNPS (Fig. 1). A mean tidal amplitude of $2.8 \mathrm{~m}$ governs current fluctuations in Cape Cod Bay. To a lesser degree wind direction/speed influences water movement. There is a general northwest/southeast tidal current fluctuation in the vicinity of the PNPS (Davis 1984). Therefore, sites were chosen on reefs southeast and northwest of the PNPS. To assess within-reef variability, we used the same methods to sample an additional site, Outer Rocky Point (ORP), about $100 \mathrm{~m}$ northeast of the IRP site.

For the among-reef comparisons (DS, WH, and IRP), habitat structure, rugosity (a measure of structure com- plexity), macroalgal canopy height, bottom water temperature, visibility, and wind direction were measured to ensure that we were not simply quantifying the differential influences of habitat and abiotic effects on recruitment across reefs. However, only habitat characteristics were measured within reefs because temperature, visibility, and wind direction were assumed to be relatively similar at adjacent sites (<100 m).

Habitat. Habitat characteristics were quantified at the beginning of the sampling season, the third week of July, and again at the end of the sampling season, the third week of October, to assess habitat stability over the season. Ten transects, each $1 \mathrm{~m}$ wide by $10 \mathrm{~m}$ long, radiating from a center mooring, $36^{\circ}$ apart, were set up at each of the 4 sites across 3 reefs for both the among- (DS, WH, and IRP) and within-reef (IRP, ORP) comparisons (Fig. 2). The center point of each fixed site was permanently marked with a mooring. The beginning of each transect was permanently marked with a rock painted yellow located $5 \mathrm{~m}$ from the center mooring to create a buffer zone, which ensured that diving activity did not disturb recruits on transects before they were counted during the recruitment survey.

Habitat characteristics (filamentous, fleshy, and crustose algal types; sand; and gravel substrate) were measured using the point intercept method (Higgins et al. 1994, Caselle \& Warner 1996) by visually determining substrate or algal type at indicated sampling points. We coded habitat characteristics into 2 functional groups, structure (filamentous and fleshy algae types) and non-structure (sand, gravel, and crustose algae), because these characteristics of the habitat are known to be important for recruitment in cunner

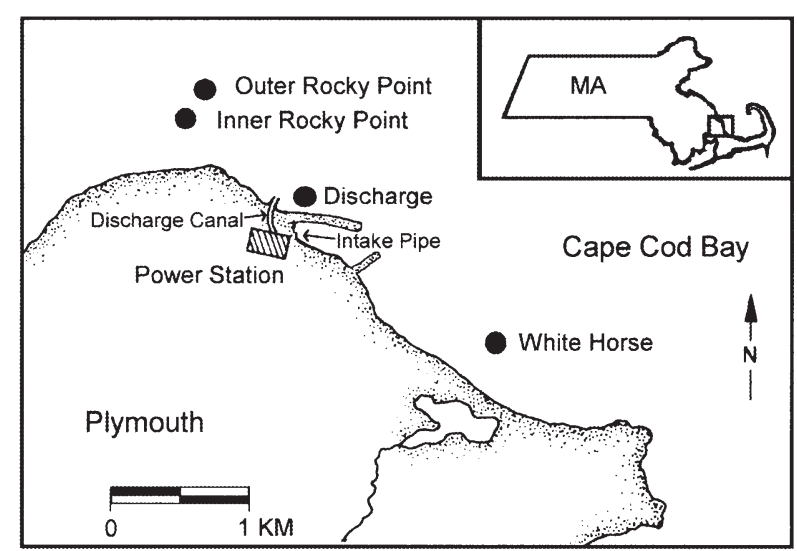

Fig. 1. Location of the 4 study sites for the cunner recruitment survey conducted in 1995 near the Pilgrim Nuclear Power Station (PNPS) in Plymouth, Massachusetts. White Horse, Discharge, and Inner Rocky Point were sampled to compare across reefs. Outer Rocky Point and Inner Rocky Point were used in a separate within-reef comparison. Location of the intake and discharge canal are also shown 

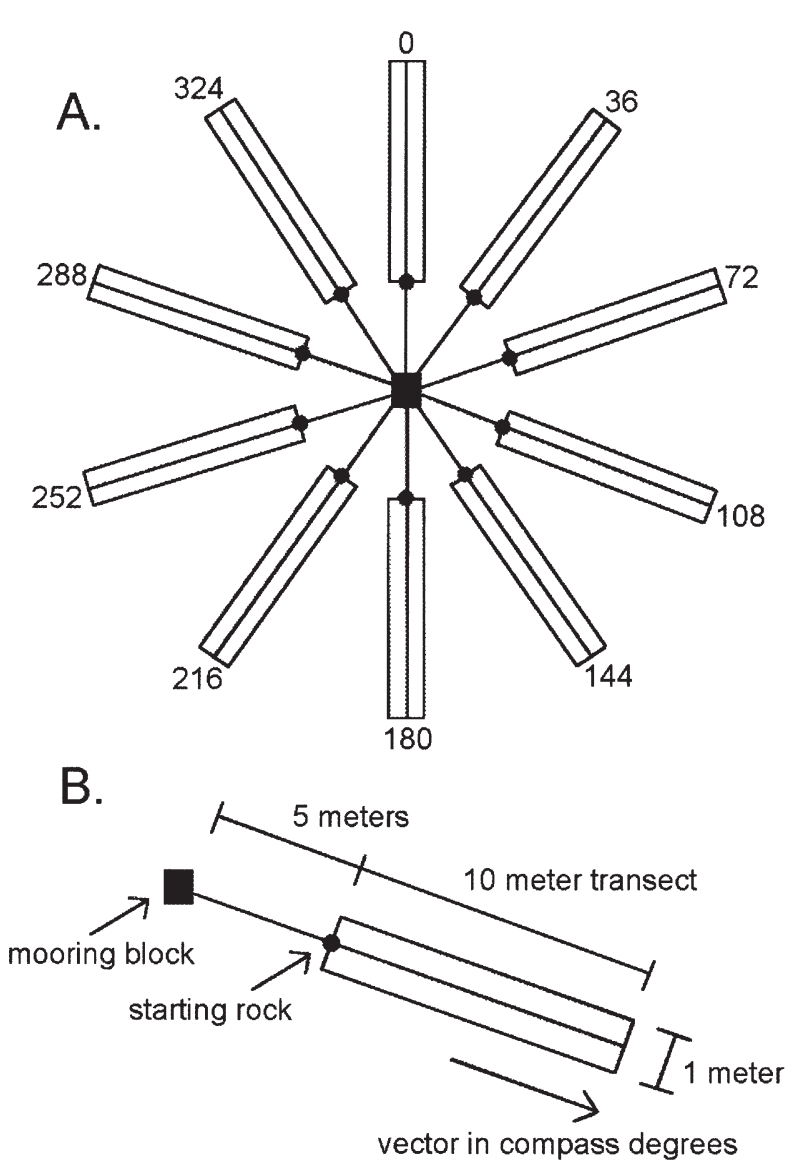

Fig. 2. (A) Transect layout used at each sample site where numbers at the end of the transect indicate transect direction. The area of each of the ten $1 \mathrm{~m} \times 10 \mathrm{~m}$ transects is depicted by a rectangle. (B) Each transect rectangle begins $5 \mathrm{~m}$ from the center mooring block, which creates a buffer area and is marked with a starting rock painted yellow

(Levin 1991, 1993, Levin et al. 1997). We define 'gravel' as rocks less then $5 \mathrm{~cm}$ in diameter with no algal cover. Boulders were not considered a category, since all boulders were covered with algae. If boulders were denuded by sea urchins, crustose algae would dominate. Habitat characteristics were visually quantified in fifty $1 \mathrm{~m}^{2}$ quadrats, randomly placed on the permanent transects at each site. String was used to partition the $1 \mathrm{~m}^{2}$ quadrat into sixteen $25 \mathrm{~cm}^{2}$ sections and habitat characteristics were measured under each of the 9 non-edge string intersection points within each quadrat. We then compared the proportion of structure to non-structure among and within reefs for each time period using chi-square analyses.

Rugosity and canopy height. Substrate rugosity is an index of structural complexity which takes into account boulder size (Tupper 1994, Tupper \& Boutilier 1995b). Rugosity was measured twice per transect in the beginning of the season (July) by laying a $10 \mathrm{~m}$ heavy brass, fine-linked chain on the bottom, such that the chain conformed to the contours of the bottom. We then measured the linear distance covered by the chain. Rugosity was calculated by dividing the distance covered by the chain length. Rugosity measurements were compared among and within reefs using analysis of variance (ANOVA). Canopy height of the algae was measured at each meter along the transect line in the beginning (July) and end (October) of the recruitment season and compared among and within reefs with an ANOVA.

Temperature, visibility, and wind direction. Temperature was recorded approximately every $2.5 \mathrm{~h}$ with thermographs mounted on the bottom at each reef. For the temperature data, we used the average of 2 temperatures taken between 06:00 $\mathrm{h}$ and noon on the days of recruit counts, since most counts were done within this time frame. After the transect counts were completed, visibility was measured at each reef using a Secchi disk held horizontally underwater. A 2-way ANOVA and post-hoc analyses using Tukey's multiple comparisons were run in which day and reef were main effects and temperature was the response variable. A second similar ANOVA was run in which visibility was the response variable. We obtained wind direction data from Boston Edison Company, which was recorded hourly at the PNPS's weather tower located $14 \mathrm{~m}$ above sea level near the discharge reef.

Recruit survey. The recruitment survey was undertaken for 41 sampling days, weather permitting, from 24 July 1995, before settlement occurred, until 7 November 1995, before recruits went into hibernation (Green \& Farwell 1971). All sites were sampled the same day because settlement, the process of larval movement from the planktonic pelagic environment to the sedentary benthic habitat, can vary on a daily basis (Levin 1994a). Within $24 \mathrm{~h}$ of settlement, cunner ( $<12 \mathrm{~mm}$ ) acquire the dark pigmentation of the adults (Levin 1993). Therefore, small pigmented fish (10 to $45 \mathrm{~mm}$, age-0) were referred to as recruits. To assess recruitment, a diver swam each of the 10 transects (Fig. 2) at each site holding a $1 \mathrm{~m}$ wide $\mathrm{T}$-bar, which delineated the width of the transect (Walton \& Bartoo 1976). A compass and a spool with $10 \mathrm{~m}$ of line mounted to the base of the T-bar indicated the direction and distance traveled. Another diver swam above and slightly in front of the navigating diver, in order to get good visual coverage of the line transect, and counted cunner recruits within the T-bar.

Two similar data analyses on 2 time periods were run for the among- and within-reef comparisons (total of 4 analyses). Specifically, each recruit data set was separated into 2 time periods, the settlement and post-settlement period with 5 September as the dividing point. We considered all counts after early Sep- 
tember to represent the post-settlement period, because cunner larvae were rare in the PNPS entrainment monitoring collections at that time (M. Scherer, Marine Research Incorporated, Falmouth, MA, unpubl. data), and no settlers (non-pigmented fish) were observed during the recruit counts after this date. For the settlement period, a multivariate repeated-measures ANOVA that treated site as the main effect, time as the repeated measure, and number of recruits as the response, was used to examine time, site, and time $\times$ site interactions. We used this multivariate ANOVA to detect overall differences in recruit abundance among- and within-reefs over the entire settlement period. Thus, this analysis determined if relative settlement differed on average among and within reefs. When an overall site difference was found, we used multiple comparisons to detect differences between all possible pairs of sites. A repeated-measures analysis was used because recruit abundance estimates were not independent among sampling days since recruits have limited movement. The multivariate repeated-measures analysis was used to remove any possible effect of an unstructured variance-covariance matrix, which is an assumption of the univariate repeated-measures analysis (von Ende 1993). In addition, we assessed the homogeneity of variance assumption using Bartlett's test (Sokal \& Rohlf 1981). Data were transformed (log $x+1$ ) as necessary to meet these assumptions.

For the post-settlement period, we again used a multivariate repeated-measures ANOVA to assess differences in sites over time. However, because we were primarily interested in the linear relationship instead of average differences, we used the first-order polynomial contrast from the trend analysis to examine overall differences among and between sites. This analysis tested for relative differences in mortality rates among and between sites. When an overall difference was detected, we used multiple contrasts to assess specifically which pairs of treatments differed.

Sensitivity analysis. To assess if values at the beginning and end of the post-settlement period disproportionately influenced our results in the first-order polynomial contrast, we ran additional repeated-measures analyses on 3 subsets of the original data as a sensitivity analysis. We first ran the same analysis described above without the last 2 sampling dates. A second data subset omitted the first $2 \mathrm{~d}$ of the post-settlement period, and the final subset omitted both the last $2 \mathrm{~d}$ and the first $2 \mathrm{~d}$ of post-settlement data. If data points at the beginning and end do not affect the analysis, similar trends should be seen in all 4 analyses: original, final points omitted, initial points omitted, initial and final points omitted. A similar analysis was also conducted for the 2-site, within-reef comparison.
Influence of abiotic factors. To assess if bottom water temperature and visibility influenced recruit abundance, we first regressed recruit count, temperature, and visibility over time in the post-settlement period for each reef. If the regression failed to indicate a significant trend through time, then the actual measurements were used because no trend needed to be accounted for in the analysis. If a trend was detected, we determined if a relationship existed between the standardized residuals of recruit abundance through time with the respective standardized residuals produced from the temperature and visibility regression models using Pearson's correlation. Residuals removed recruit mortality rates, temperature, and visibility trends through time. Therefore, correlations between standardized residuals of recruits and physical factors extracted the underlying relationship between the variables.

A Pearson's correlation, comparing the standardized residuals from the recruit abundance through time regression at the discharge reef to the time of last onshore wind (Frank \& Leggett 1981) determined if wind direction was important in influencing recruitment. 'Time-since-last-onshore-wind' was used because counts were made only when an offshore wind or when a very light onshore wind $\left(<10 \mathrm{~km} \mathrm{~h}^{-1}\right)$ existed. Only the discharge recruit abundance data were used, since a single measure of wind direction existed near the PNPS.

\section{RESULTS}

\section{Habitat, temperature, and visibility}

No significant difference existed in the proportion of structure to non-structure habitat among-reefs either early or late in the season (Fig. 3A,B). There was, however, a significant decrease $(10 \%)$ in the structural proportion at all sites across the season (Fig. 3A vs $B_{i}$ July-October, df $=2, \chi^{2}=46.65, \mathrm{n}=4443, \mathrm{p}<0.001$ ). No significant difference was detected in the rugosity index among reefs $(\mathrm{df}=2, F=0.20, \bar{x}=0.587, \mathrm{n}=60$, $\mathrm{p}=0.816$; data not shown). No differences were detected in canopy height (early, df $=2, F=1.96, \bar{x}=$ $9.2, \mathrm{n}=311, \mathrm{p}=0.141$; late, $\mathrm{df}=2, F=2.54, \bar{x}=5.6, \mathrm{n}=$ $330, \mathrm{p}=0.078$; data not shown) among reefs for either the beginning or end of the season. However, canopy height did change across season ( $\mathrm{df}=1, F=50.98, \mathrm{n}=$ 596, p $<0.001$, data not shown), with the canopy height being an average of $3.4 \mathrm{~cm}$ lower in the late (October) analysis. No difference in temperatures existed among reefs (Fig. 4A-C, Table $1 ; \mathrm{p}=0.0848$ ). However, visibility did differ among reefs with DS and IRP having similar visibilities to each other but lower visibility than 


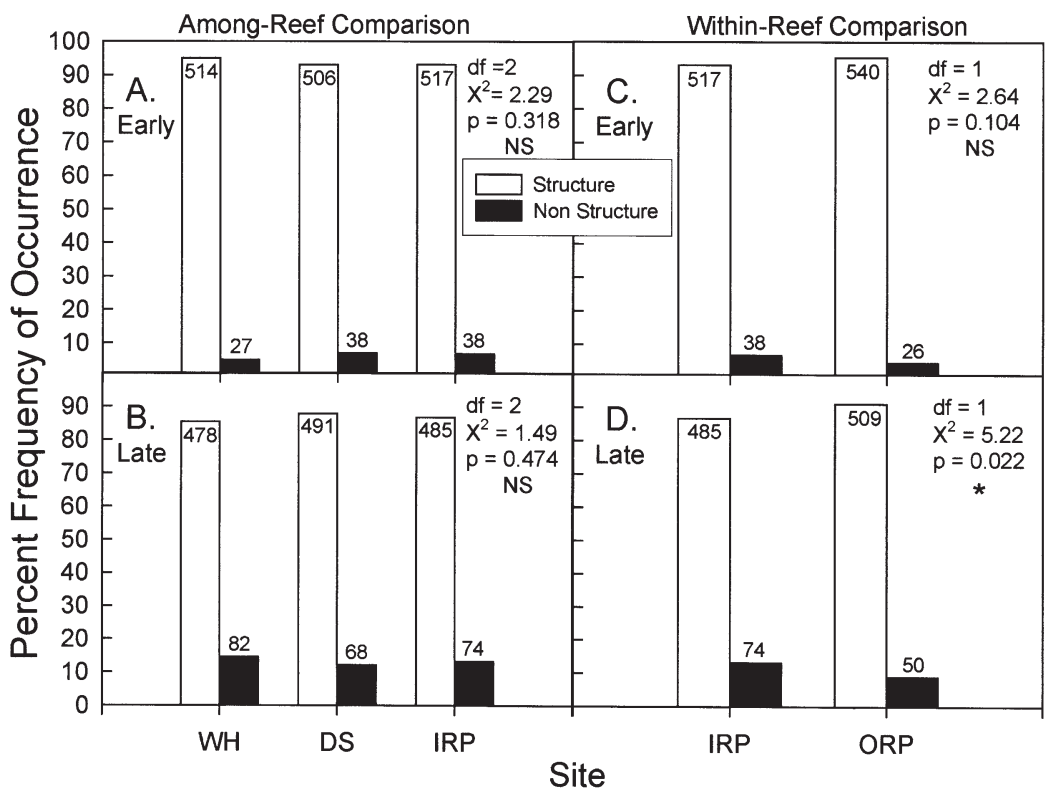

Fig. 3. Percent frequency of occurrence of structure and non-structure habitat that existed among $(A, B)$ and within reefs $(C, D)$, early (3rd week of July; $A, C$ ) and late (3rd week of October; B,D) in the recruitment season. Site differences within each time period were tested using chi-square. Across-reef comparisons were made among WH (White Horse), DS (Discharge), and IRP (Inner Rocky Point). IRP and ORP (Outer Rocky Point) were used to assess within-reef differences. ${ }^{*}$ Significance at the 0.05 level; NS: non-significant differences. Degrees of freedom (df) and chi-square statistics $\left(\chi^{2}\right)$ are also shown. Actual number of occurrences are shown at the top of each bar used for visibility because a significant trend did not exist over time at each site for this variable (Fig. 5G-I). A significant negative correlation was detected between the standardized residuals from the recruit abundance and temperature models (Fig. 6A). Thus, temperature changes could have influenced recruit counts over time, but similar temperature trends occurred among reefs and, therefore, differential influences of temperature among reefs did not exist. No significant correlation was found between the standardized residuals of recruit counts and visibility through time (Fig. 6B); neither was one found between the standardized residuals of the recruit counts and hours since last onshore wind (Fig. 6C).

\section{Among-reef recruitment}

No recruits were observed on the first sampling date, 24 July (Fig. 7). Recruit abundance increased rapidly through the settlement period to a mean of 157 fish per $10 \mathrm{~m}^{2}$ at the discharge reef on 22 August and declined

WH (Fig. 4D-F; DS = 5.7, IRP $=5.2$, $\mathrm{WH}=6.9$; Tukey's multiple comparison, Table 1).

\section{Overall influence of abiotic factors}

All recruit abundance and temperature regressions were significant over time; hence, the standardized residuals for these 2 variables were used in the correlation analysis (Fig. 5A-F). A linear least-square regression was used on the natural log transformed mean recruit count of the 10 transects at each reef (Fig. 5A-C). A partial $F$-test indicated the quadratic leastsquare model provided a significantly better fit than the linear relationship for the temperature data over the post-settlement period at each reef (Fig. 5D-F; DS, $F=15.229, \mathrm{p}<0.001$; IRP, $F=19.053, \mathrm{p}<0.001 ; \mathrm{WH}, F=$ 17.097, $\mathrm{p}<0.001)$. Actual data, rather than standardized residuals, were

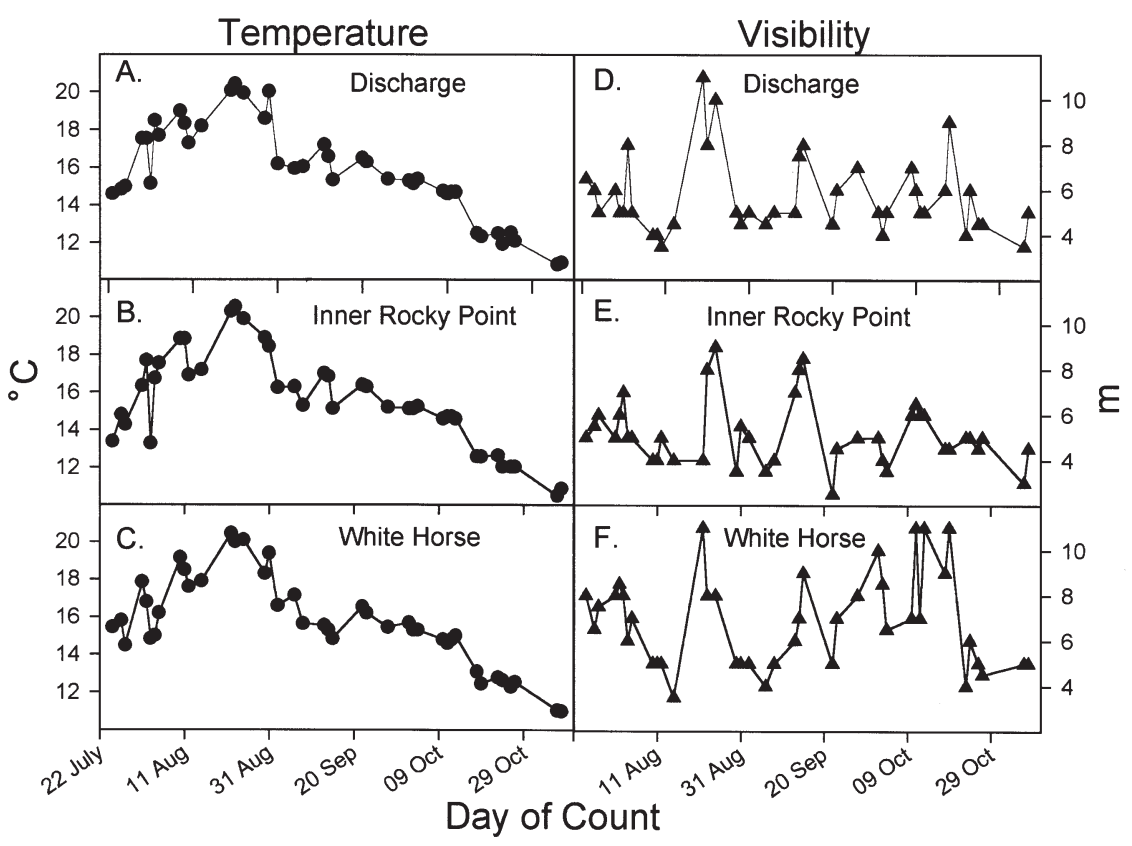

Fig. 4. (A-C) Changes in temperature and (D-F) visibility that occurred over the season and among reefs for days when recruits counts were done 
Table 1. Comparison of temperature and visibility measurements among reefs and over time using 2-way ANOVAs

\begin{tabular}{|lrrrr|}
\hline Effect & df & \multicolumn{1}{c}{ SS } & \multicolumn{1}{c|}{$F$} & \multicolumn{1}{c|}{$p$} \\
\hline Temperature & & & & \\
Reef & 2 & 1.35 & 2.54 & 0.0848 \\
Day & 40 & 719.08 & 67.91 & $<0.0001$ \\
Error & 80 & 21.18 & & \\
Visibility & & & & \\
Reef & 2 & 61.25 & 18.09 & $<0.0001$ \\
Day & 40 & 241.85 & 3.57 & $<0.0001$ \\
Error & 80 & 135.42 & & \\
\hline
\end{tabular}

in the post-settlement period from 5 September to 7 November (Fig. 7). Recruit abundance over the settlement period differed through time (Fig. 7, repeatedmeasures ANOVA, Wilks' lambda, Table 2; time effect, $\mathrm{p}<0.0001$ ), among-reefs (Table 2; reef effect, $\mathrm{p}<$ 0.0001 ), and among reefs through time (Table 2 ; time $\times$ reef interaction, $\mathrm{p}<0.0001)$. DS had higher recruit densities in the settlement period than either IRP or WH (Table 2; multiple comparisons).

Recruit densities among reefs at the beginning of the post-settlement period differed, with DS having higher densities than the other 2 reefs, but densities did not differ by the end of the season (Fig. 7). Decline in recruit abundance through time was linear (Table 2; linear effect, $\mathrm{p}<0.0001$ ) and differed among reefs
(Table 2; reef effect, $\mathrm{p}<0.0001)$. Furthermore, posthoc tests indicated that post-settlement mortality rates at all reefs differed significantly from each other (Table 2; reef effect, p $<0.0001$ ).

Overall differences in cunner recruit mortality rates among reefs persisted in the sensitivity analysis regardless of the data set used (Table 3). Differences in mortality rates between DS and $\mathrm{WH}$ and between $\mathrm{WH}$ and IRP also persisted regardless of the data set used. However, differences in mortality rates at DS and IRP were no longer significantly different when data in the first 2 post-settlement samples were deleted or when both the beginning and final data points were omitted (Table 3).

\section{Within-reef habitat}

Early in the season, no significant difference in the proportion of structure to non-structure was observed (Fig. 3C), but a significant difference was detected between sites late in the season, with ORP having a slightly higher proportion $(4.3 \%)$ of structure than IRP (Fig. 3D). For the within-reef analysis no significant difference was detected for rugosity ( $\mathrm{df}=1, F=0.53$, $\bar{X}=0.576, \mathrm{n}=40, \mathrm{p}=0.470$; data not shown), but a significant difference in height was detected early in the season with ORP having a slightly higher canopy height than IRP $(9.5$ and $7.8 \mathrm{~cm}$, respectively, $\mathrm{df}=1$,

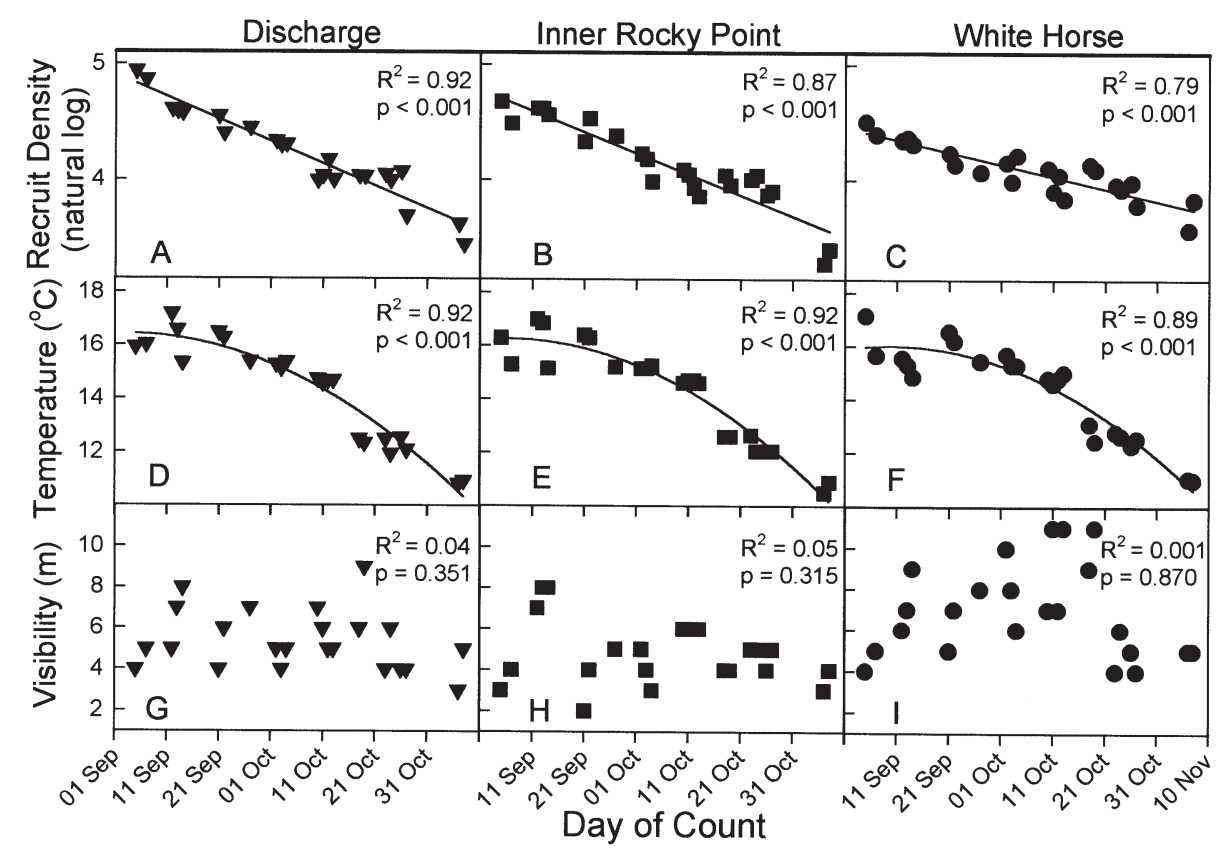

Fig. 5. Plots of the least-square regression models used to produce the standard residuals and account for the (A-C) recruit mortality rates, and (D-F) temperature trend across the post-settlement period at each reef. No apparent trend needs to be accounted for in the visibility measurements (G-I) over the post-settlement period 


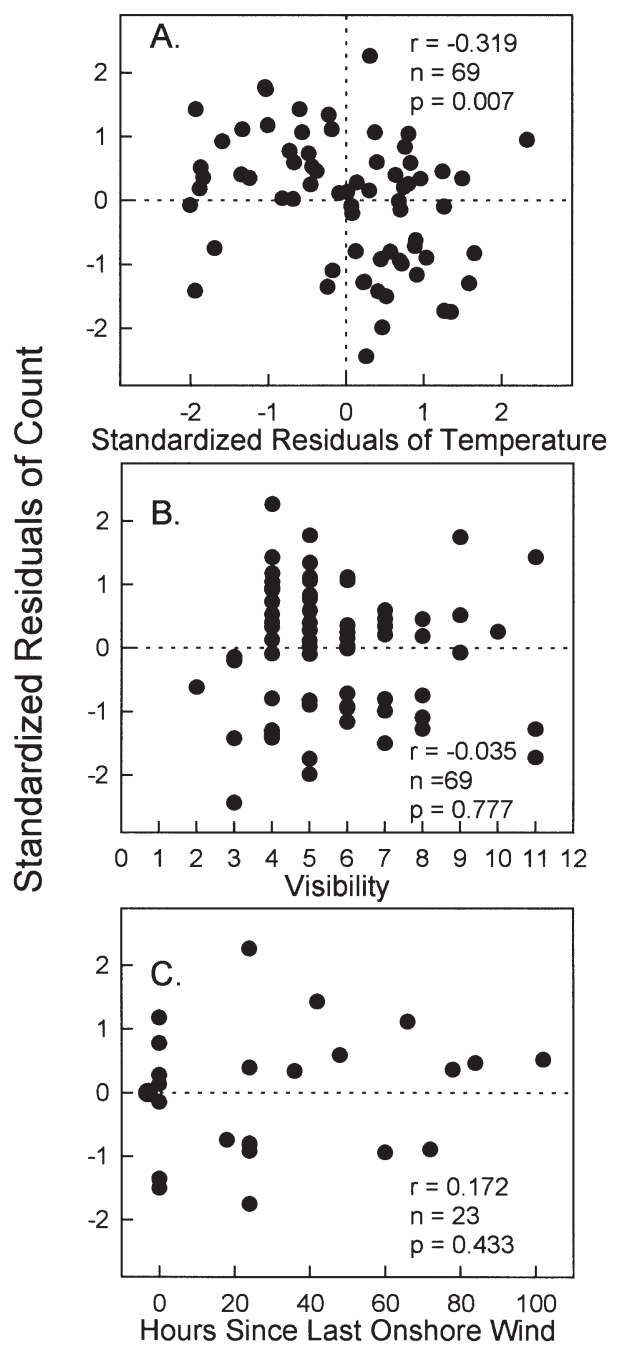

Fig. 6. Relationships between (A) standardized residuals for cunner recruit counts and standardized residuals of temperature (A) and (B) visibility measurements are plotted for all reefs combined over the post-settlement period. (C) Comparison of standardized residuals of recruit counts to hours since last onshore wind for the DS reef. Residuals are calculated from the regressions seen in Fig. 5. Corresponding Pearson's correlations are reported on each plot

$F=5.44, \mathrm{n}=219, \mathrm{p}=0.0206$; data not shown). However, heights were similar between sites late in the season $(\mathrm{df}=1, F=2.37, \bar{x}=5.5, \mathrm{n}=220, \mathrm{p}=0.126$; data not shown).

\section{Within-reef recruitment}

Within a reef (IRP and ORP), the mean number of cunner recruits increased through time to a peak of 120 per $10 \mathrm{~m}^{2}$ on 1 September, then declined through the end of the season, 7 November (Fig. 8). During set- tlement, recruit abundance at both IRP and ORP increased significantly through time (Table 2; repeatedmeasures ANOVA, time effect, $\mathrm{p}=0.0069$ ). However, recruit densities between sites over the settlement period differed significantly (Table 2; site effect, $\mathrm{p}=$ $0.0468)$. The time $\times$ site interaction was not significant (Table 2 ; time $\times$ site interaction, $\mathrm{p}=0.747$ ) .

Recruit densities in the post-settlement period at both IRP and ORP were similar in the beginning of the post-settlement period, but densities decreased in a linear fashion (mortality rate) and diverged by the end of the season (Table 2; linear effect, $p<0.0001$ ). Furthermore, mortality rates differed between sites, with ORP having a lower mortality rate than IRP (Fig. 8 , Table 2 ; reef effect, $\mathrm{p}=0.0006)$. The sensitivity

Table 2. Multivariate repeated-measures ANOVA results in the among- and within-reef comparisons of the settlement period for the time effect, the mean difference among and between sites, and the time $\times$ site interaction and of the post-settlement period for the first-order polynomial contrasts testing the linear trend and the linear trend among and between sites of recruit counts. Individual contrasts between reefs for the mean difference in the settlement period and the linear trends in the post-settlement period are also shown. For the time and the time $\times$ site interaction in the settlement period, $F$ and $\mathrm{p}$ values are based on Wilks' lambda statistics. SS: type-III sum of squares, -: no SS values

\begin{tabular}{|lrccc|}
\hline Effect & df & SS & $F$ & $p$ \\
\hline AMONG-REEF & & & & \\
Settlement & & & & \\
Time & 17 & - & 442.23 & $<0.0001$ \\
Reef & 2 & 164033.43 & 174.79 & $<0.0001$ \\
Time $\times$ Reef & 34 & - & 14.22 & $<0.0001$ \\
Error & 27 & 12669.32 & & \\
WH vs DS & 1 & 113316.03 & 241.49 & $<0.0001$ \\
WH vs IRP & 1 & 714.03 & 1.52 & 0.228 \\
DS vs IRP & 1 & 132020.1 & 281.35 & $<0.0001$ \\
Post-settlement & & & & \\
Linear & 1 & 264111.29 & 988.38 & $<0.0001$ \\
Reef & 2 & 23385.8 & 43.76 & $<0.0001$ \\
Error & 27 & 7214.84 & & \\
WH vs DS & 1 & 22537.74 & 84.34 & $<0.0001$ \\
WH vs IRP & 1 & 10056.63 & 37.63 & $<0.0001$ \\
DS vs IRP & 1 & 2484.32 & 9.3 & 0.0051 \\
WITHIN-REEF & & & & \\
Settlement & & & & \\
Time & 17 & - & 143.99 & 0.0069 \\
Site & 1 & 756.9 & 4.56 & 0.0468 \\
Time $\times$ Site & 17 & - & 0.67 & 0.747 \\
Error & 18 & 2990.53 & & \\
Post-settlement & & & & \\
Linear & 1 & 169788.29 & 1709.46 & $<0.0001$ \\
Site & 1 & 1696.18 & 17.08 & 0.0006 \\
Error & \multicolumn{5}{c}{1787.81} & & \\
& & & & \\
\hline
\end{tabular}




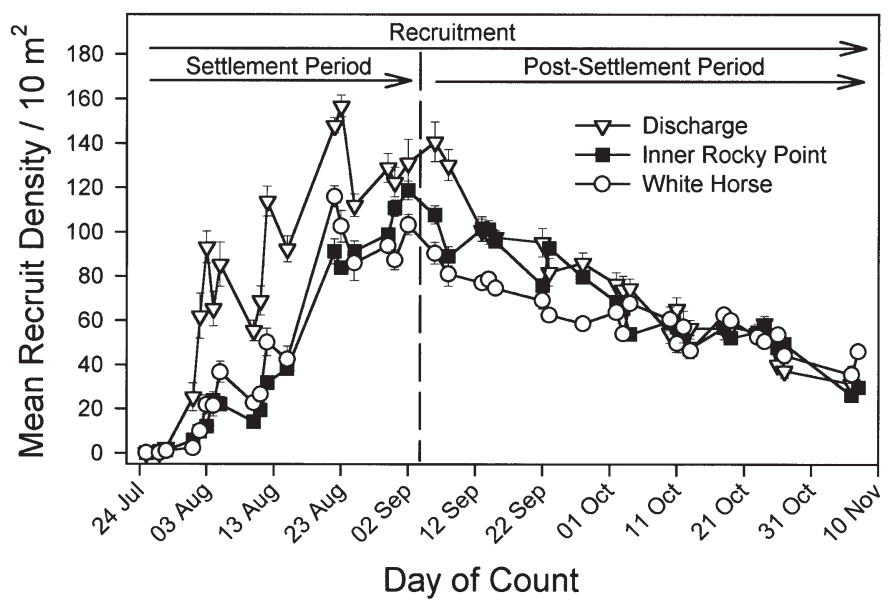

Fig. 7. Mean cunner recruit counts for the 10 transects on 3 isolated boulder reefs over the entire recruitment period. Data are means $\pm 1 \mathrm{SE}$. The break-up of recruit counts into the settlement and post-settlement period is shown with a dashed line

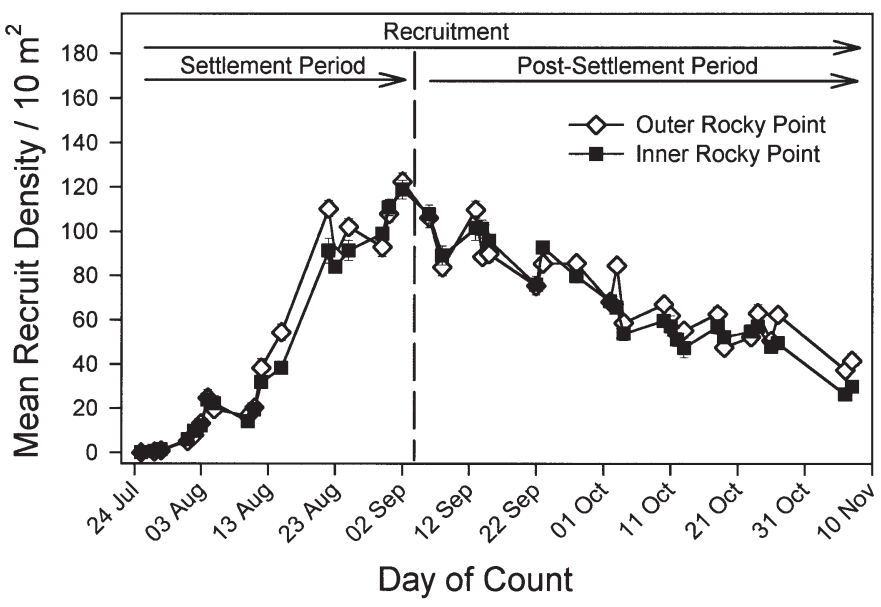

Fig. 8. Mean cunner recruit counts for the 10 transects at 2 sites $100 \mathrm{~m}$ apart within the same boulder reef over the entire recruitment period. Data are mean $\pm 1 \mathrm{SE}$. The break-up of recruit counts into the settlement and post-settlement period is shown with a dashed line

analysis compared 3 subsets of data, i.e., (1) without the first $2 d_{1}$ (2) without the last $2 d$, and (3) without both the first and last $2 \mathrm{~d}$ of recruit density data, to assess if extreme points exerted undue influence on the results. The analysis from the different subsets of data produced similar results regardless of which data set was used (last $2 \mathrm{~d}$ omitted: $\mathrm{SS}=991.87, \mathrm{df}=1, F=$ 11.29, $\mathrm{p}=0.0035$; first $2 \mathrm{~d}$ omitted: $\mathrm{SS}=1247.6, \mathrm{df}=1$, $F=19.14, \mathrm{p}=0.0004$; both last and first $2 \mathrm{~d}$ omitted: $\mathrm{SS}=648.09, \mathrm{df}=1, F=8.64, \mathrm{p}=0.0088$; data not shown).
Table 3. Comparison of the overall and multiple contrast statistics among reefs to assess sensitivity of data on the extremities of the original data, with subsets of data having different days deleted from the post-settlement period using multivariate repeated-measures linear trend analysis. SS: type-III sum of squares

\begin{tabular}{|lrrrr|}
\hline Effect & All data & $\begin{array}{c}\text { Omit last } \\
2 \mathrm{~d}\end{array}$ & $\begin{array}{c}\text { Omit first } \\
2 \mathrm{~d}\end{array}$ & $\begin{array}{c}\text { Omit first } \\
\text { and last 2 d }\end{array}$ \\
\hline Among reef & & & & \\
Reef SS & 23386 & 19128 & 13810 & 9837 \\
Error SS & 7215 & 4989 & 4923 & 2319 \\
F & 43.76 & 51.75 & 37.87 & 57.27 \\
p & $<0.0001$ & $<0.0001$ & $<0.0001$ & $<0.0001$ \\
DS vs IRP & & & & \\
Reef SS & 2484 & 3232 & 0.669 & 13 \\
F & 9.3 & 17.49 & 0 & 0.15 \\
p & 0.0051 & 0.0003 & 0.9522 & 0.6983 \\
DS vs WH & & & & \\
Reef SS & 22538 & 18937 & 10274 & 7683 \\
F & 84.34 & 102.48 & 56.35 & 89.46 \\
p & $<0.0001$ & $<0.0001$ & $<0.0001$ & $<0.0001$ \\
WH vs IRP & & & & \\
Reef SS & 10057 & 6522 & 10440 & 7060 \\
F & 37.63 & 35.29 & 57.26 & 82.2 \\
p & $<0.0001$ & $<0.0001$ & $<0.0001$ & $<0.0001$ \\
& & & & \\
\hline
\end{tabular}

\section{DISCUSSION}

\section{Habitat}

Examining possible influences of factors such as habitat on cunner recruitment among reefs was a prerequisite for the interpretation of cunner recruitment patterns and density-dependent effects. It is also important to note that after settlement an overall decrease in recruit abundance at a reef was assumed to be mortality since cunner recruits possess very limited movement (Tupper \& Boutilier 1995a, 1997). Numerous studies have found that differences in macroalgae type and structure are essential determinants of recruitment in temperate reef fish species (Jones 1984, Carr 1989, 1991, 1994, Connell \& Jones 1991, Levin 1991, 1993, 1994b, Levin et al. 1997). For example, structural quality of habitat is known to be an important determinant of post-settlement recruit abundance in cunner (Levin 1993, 1994b, Tupper \& Boutilier 1995a). Our results showed that within a sampling period, the proportion of structure and non-structure habitat, rugosity, and macroalgae height were similar among our study reefs and were therefore likely not responsible for different patterns of recruitment among reefs.

However, in the within-reef comparison, a small difference in macroalgal canopy height between sites at the beginning of the season, and the emergence of a 
small difference in the proportion of structure and nonstructure between sites at the end of the season, appeared to correspond to differences in post-settlement mortality rates. These observations suggest that even small differences in the proportion of macroalgae appear to influence mortality rates and subsequent recruitment at a smaller spatial scale. In addition, the structural component and algal height both among and within reefs decreased from the beginning to the end of the season. This change over the season is likely due to an increase in high-velocity onshore winds in the fall which results in the removal of loose macroalgae (Davis 1984). Because cunner recruitment at a small spatial scale appears to be influenced by small differences in habitat structure, abiotic factors that influence habitat during the recruitment season, such as wave action and storm events, may be important to recruitment and should be monitored when comparing recruitment among sites.

\section{Temperature}

Temperature likely did not confound the disturbance or density effects among reefs because no differences in temperature existed across reefs. However, for all reefs combined, a significant negative temperaturerecruit correlation in the residuals indicated that temperature explained some of the daily variation in recruit counts. Our correlation analysis using regression-model residuals eliminated spurious correlations resulting from similar temporal trends, such as decreases in recruit abundance due to mortality and temperature decreases related to seasonality. The relationship we observed between changes in temperature between consecutive sampling days (not the temperature trends across season) and cunner activity suggests that recruits were more active when temperatures were lower than the overall temperature trend explained by the regression model. These patterns may be the result of prolonged nocturnal torpor, when cunner reside in crevices between the boulders of the reef at a reduced metabolic rate (Olla et al. 1975, Tupper 1994). Cunner recruits appeared to be less active when temperatures were higher than the overall temperature trend. Cunner are reported to be diurnally active when water temperatures increase above 5 to $7^{\circ} \mathrm{C}$ and inactive below this threshold (Green \& Farwell 1971, Dew 1976, Pottle \& Green 1979a,b, Green at al. 1984). However, our observations suggest that water-temperature fluctuations between 10 and $18^{\circ} \mathrm{C}$ can influence daily activity as well. Thus, our results indicate that, although temperature does not affect our across-reef comparison, it is a factor that can potentially influence the measure of recruitment and needs to be exam- ined further relative to cunner physiology, activity, and behavior.

\section{Visibility and wind direction}

Visibility was the only factor which differed significantly among reefs. This variation probably did not affect recruitment among reefs because no relationship existed in the residual analysis. Specifically, when all reefs and post-settlement dates were examined, daily changes in visibility did not correspond to daily changes in recruit counts. In addition, visibility never decreased to the point that we had trouble seeing recruits within a $2 \mathrm{~m}$ distance. Thus, visibility may differ across reefs, but this difference does not appear to affect recruit abundance, and consequently, we can still assess density effects by using recruit counts among reefs.

The comparison of time since last onshore wind with the residuals of cunner recruit mortality rates indicated that overall wind direction and wave action did not strongly influence mortality. Therefore, wind directions likely did not play a pivotal role in influencing recruitment during our study. However, wave action related to wind direction could play a more important role in a recruitment season where storm events physically alter habitat quality by removing macroalgae that serve as cover for cunner.

\section{Settlement}

We attempted to use recruit counts at 3 reefs as a tool for assessing density effects, because habitat and abiotic factors including, temperature, visibility, and wind direction did not explain differences in recruitment among reefs. Power-plant entrainment and hydrodynamic effects primarily will only occur on the pelagic egg and larva stages and are unlikely to continue to have a direct impact on recruits after settlement. In our interpretation of recruit abundance, we assume the PNPS can only have an effect on mortality of the presettlement pelagic egg and larval stages, since habitat and abiotic factors measured also suggested the PNPS did not have differential influences among reefs. Therefore distance of the reef to the disturbance was not considered an important factor in the interpretation of mortality rates of post-settlers. However distance of the reef to the disturbance may be a factor for settlement and therefore affect recruit abundance in the settlement period. Assessing the differential effects of the PNPS on settlement among reefs without information on larva densities and water movements is beyond the scope of this study. We only used the settlement period 
to determine if evidence existed for differences in settlement among reefs. Changes in cunner abundance during the settlement period are the result of 2 processes: the influx of new recruits and the decrease in number of existing recruits through mortality. Even though we do not know which process was more important between sampling days, average recruit abundance over the entire settlement period should be an appropriate depiction of the relative amount of settlement at each reef. Over the settlement period we found significantly higher recruit abundance at the discharge reef near the PNPS in comparison to other reefs. Therefore, our results indicate that differences in settlement occurred among reefs with higher settlement occurring at the discharge reef.

Local hydrodynamics could be a possible explanation for the higher settlement near the PNPS. An eddy produced from the PNPS's discharge current may enable more larvae to settle in a relatively small area at the reef near the PNPS. Further investigation on factors affecting settlement rates are needed to help explain the across-reef settlement patterns observed herein but are not critical to interpreting results in the post-settlement period.

\section{Post-settlement}

Differences in settlement likely produced the differences in recruit densities among reefs at the beginning of the post-settlement period. The discharge reef nearest the PNPS had the highest recruit densities at the beginning of the post-settlement period and the highest mortality rate, making it difficult to distinguish density-dependent mortality from a PNPS effect. However, a mechanism for impact by the PNPS on cunner recruits after settlement is not obvious since habitat and abiotic factors measured suggested very similar conditions among reefs. Regardless, the PNPS cannot be entirely ruled out as a possible influence on mortality rates in the post-settlement period, since the highest mortality rate was found at the site nearest the disturbance. If, as we suspect, the higher mortality rate at the PNPS reef is not related to a direct PNPS effect, then post-settlement results provide evidence for density-dependent mortality and suggest the cunner population was regulated at the post-settlement stage.

Evidence for density dependence in the vicinity of the PNPS suggests that entrainment mortality by the power plant will not translate into a direct effect on population size. These results therefore imply that observations of cunner recruit trends in the post-settlement period were valuable to the assessment of the relative impact of the PNPS. However, a disturbance could play a more important role in influencing recruit- ment during a season of lower larval abundance when power-plant entrainment could reduce recruit abundance through a direct relationship between larval supply, settlement, and recruitment. Even though our data suggest density-dependent mortality occurred, it is the sum of the recruitment processes occurring over several years which govern future stock abundance, and therefore longer-term studies of recruitment under the influences of a disturbance are needed for the thorough assessment of the disturbance effect.

In our study, a relationship existed between cunner recruit densities in the settlement period and the relative density of recruits 2 wk after the last observed settler. Levin (1996) also found a significant relationship between settlement and density of cunner recruits 2 wk after the last observed settler (late August in his study). We also found evidence of density-dependent mortality, but it was not detected until approximately 5 wk after settlement ended. Similarly, Tupper \& Boutilier (1995a) also observed density-dependent processes occurring over a $6 \mathrm{wk}$ period in an experiment where various cunner recruit densities were stocked among sites at the beginning of the post-settlement period. The manipulated high-density site in Tupper \& Boutiler's (1995a) study was stocked at approximately 10 fish $\mathrm{m}^{-2}$, which is similar to the observed densities in the beginning of the post-settlement period at our high-density reef (14 fish $\mathrm{m}^{-2}$ ). Therefore, density-dependent mortality is a plausible explanation for the mortality pattern at cunner densities observed in our study.

Evidence of density dependence were consistent regardless of the data set used in the sensitivity analysis. Inner Rocky Point was sensitive to deletions of count data at the beginning of the post-settlement period, which is possibly the result of a pulse of additional settlement late in the settlement period at that reef. However, differences in mortality rates between the White Horse and discharge sites persisted for all data sets, indicating that evidence of density-dependent mortality was not sensitive to the break-up dates between the settlement and post-settlement periods.

The potential mechanisms for density-dependent mortality were not a focus of this study and remain unknown. However, the quality of the habitat as a refuge from predation has been shown to determine recruitment success. For example, Tupper (1994) and Tupper \& Boutilier (1995b, 1997) found cunner and cod recruitment success to be dependent on predator attack success mediated through the structural quality of the habitat. Similarly, Steele (1997) found that density-dependent predation masked initial recruitment patterns on standardized habitat units for 2 temperate reef fishes (gobies). Density-dependent predation is consistent with our finding of a rapid decline in recruit 
abundance in a relatively short time period and the apparent importance of a relatively small change in the habitat structure to mortality in the within-reef comparison (Hixon 1991, Hixon \& Beets 1993). However competition for space could also produce a similar pattern (Smith 1978).

\section{Large- versus small-scale comparison}

It is unclear why an overall significant difference in recruit abundance was observed in the settlement period within the Rocky Point reef, since larval supply should not vary greatly between sites that are near each other $(<100 \mathrm{~m})$ and recruit abundance was similar between consecutive sampling days. Consequently, detecting significant differences in recruit abundance is probably the result of observing higher recruit densities at the ORP site on 3 of the 18 sampling days. However, detecting a significant difference in recruit abundance could also be the result of differences in mortality rates and not differences in settlement between sites. Differences in mortality between sites could have resulted from habitat differences, since canopy height measurements between sites differed in the settlement period. Nevertheless, within-reef postsettlement mortality also appeared to be influenced by differences in habitat structure that emerged through time rather than differences in recruit abundance at the beginning of the post-settlement period. Furthermore, significant differences in mortality rates were robust to omission of sampling days in the sensitivity analysis, indicating that small differences in mortality rates did exist. Therefore, at the smaller spatial scale (within-reef), differing habitats, rather than initial recruit density, could explain mortality differences; whereas, at the larger spatial scale (among-reef), density-dependent mortality was evident because habitats were similar and initial recruit densities differed. In conclusion, results of the examination of recruitment at 2 spatial scales reinforced the importance of examining both density and habitat when evaluating recruitment dynamics or environmental perturbation effects.

Acknowledgements. This study was supported by Boston Edison Company, Massachusetts Division of Marine Fisheries, University of Massachusetts Department of Forestry and Wildlife Management, and the Massachusetts Cooperative Fish and Wildlife Research Unit. We would like to thank Erin Casey and Beth Starr for their help in the field. We would like to thank everyone at the Massachusetts Division of Marine Fisheries who contributed to the intensive scuba diving required to accomplish this research, especially John Chisholm, Brian Kelly, and Vincent Malkoski. In addition, we are grateful to Robert Lawton for providing the resources which made this study possible. We thank Robert Anderson of
Boston Edison, Leigh Bridges of the Massachusetts Division of Marine Fisheries, and the Pilgrim Nuclear Power Station Administrative and Technical committee for their foresight and cooperation in initiating this project. John Boreman and Mark Tupper provided constructive comments. We would also like to thank Steve Murawski, Frank Steimle, Fred Serchuk, and Mark Terceiro for their review of the manuscript. The Massachusetts Cooperative Fish and Wildlife Research Unit is jointly sponsored by the USGS Biological Resources Division, the University of Massachusetts Department of Natural Resources Conservation, the Massachusetts Division of Marine Fisheries, the Massachusetts Division of Fisheries and Wildlife, and the Wildlife Management Institute.

\section{LITERATURE CITED}

Bigelow HB, Schroeder WC (1953) Fishes of the Gulf of Maine, Vol 53. Fish Bull US Fish and Wildlife Service, US Government Printing Office, Washington, DC

Boreman J, Goodyear CP (1988) Estimates of entrainment mortality for striped bass and other fish species inhabiting the Hudson River estuary. In: Barnthouse LW, Klauda RJ, Vaughan DS, Kendall RL (eds) Science, law, and Hudson River power plants: a case study in environmental impact assessment. American Fisheries Society Monograph 4, Bethesda, MD, p 152-160

Carr MH (1989) Effects of macroalgal assemblages on the recruitment of temperate zone reef fishes. J Exp Mar Biol Ecol 126:59-76

Carr MH (1991) Habitat selection and recruitment of an assemblage of temperate zone reef fishes. J Exp Mar Biol Ecol 146:113-137

Carr MH (1994) Effects of macroalgal dynamics on recruitment of a temperate reef fish. Ecology 75:1320-1330

Caselle JE (1999) Early post-settlement mortality in a coral reef fish and its effect on local population size. Ecol Monogr 69:177-194

Caselle JE, Warner RR (1996) Variability in recruitment of coral reef fishes: the importance of habitat at two spatial scales. Ecology 77:2488-2504

Connell SD, Jones GP (1991) The influence of habitat complexity on post-recruitment processes in a temperate reef fish population. J Exp Mar Biol Ecol 151:271-294

Davis JD (1984) Western Cape Cod Bay: hydrographic, geological, ecological, and meteorological backgrounds for environmental studies. In: Davis JK, Merriman K (eds) Observations on the ecology and biology of Western Cape Cod Bay, Massachusetts. Springer-Verlag, New York, p 1-18

Dew CB (1976) A contribution to the life history of the cunner, Tautogolabrus adspersus, in Fishers Island Sound, Connecticut. Chesapeake Sci 17:101-113

Doherty PJ (1982) Coral reef fishes: recruitment-limited assemblages? Proc 4th Int Coral Reef Symp, Manila 2: 465-470

Doherty PJ (1983) Tropical territorial damselfishes: is density limited by aggression or recruitment? Ecology 64:176-190

Doherty PJ, Fowler AJ (1994) An empirical test of recruitment limitation in a coral reef fish. Science 263:935-939

Forrester GE (1995) Strong density-dependent survival and recruitment regulate the abundance of a coral reef fish. Oecologia 103:275-282

Frank KT, Leggett WC (1981) Wind regulation of emergence times and early larval survival in capelin (Mallotus villosus). Can J Fish Aquat Sci 38:215-223

Goodyear CP (1988) Implications of power plant mortality for 
management of the Hudson River striped bass fishery. In: Barnthouse LW, Klauda RJ, Vaughan DS, Kendall RL (eds) Science, law, and Hudson River power plants: a case study in environmental impact assessment. American Fisheries Society Monograph 4, Bethesda, MD, p 245-254

Green JM (1975) Restricted movements and homing of the cunner, Tautogolabrus adspersus (Walbaum) (Pisces: Labridae). Can J Zool 53:1427-1431

Green JM, Farwell M (1971) Winter habits of the cunner, Tautogolabrus adspersus (Walbaum 1872) in Newfoundland. Can J Zool 49:1497-1499

Green JM, Martel G, Martin DW (1984) Comparison of the feeding activity and diets of male and female cunners Tautogolabrus adspersus (Pisces: Labridae). Mar Biol 84:7-11

Grocki W (1984) Algal investigations in the vicinity of Plymouth, Massachusetts. In: Davis JK, Merriman K (eds) Observations on the ecology and biology of Western Cape Cod Bay, Massachusetts. Springer-Verlag, New York, p 19-55

Higgins KF, Oldemeyer JL, Jenkins KJ, Clambey GK, Harlow RF (1994) Vegetation sampling and measurement. In: Bookhout TA (ed) Research and management techniques for wildlife and habitats. The Wildlife Society, Bethesda, MD, p 567-591

Hixon MA (1991) Predation as a process structuring coral-reef fish communities. In: Sale PF (ed) The ecology of fishes on coral reefs. Academic Press, San Diego, CA, p 475-508

Hixon MA, Beets JP (1993) Predation, prey refuges and the structure of coral-reef fish assemblages. Ecol Monogr 63: $77-101$

Jones GP (1984) Population ecology of the temperate reef fish Pseudolabrus celidotus Bloch \& Schneider (Pisces: Labridae). I. Factors Influencing recruitment. J Exp Mar Biol Ecol 75:257-276

Jones GP (1991) Post-recruitment processes in the ecology of coral reef fish populations: a multifactorial perspective. In: Sale PF (ed) The ecology of fishes on coral reefs. Academic Press, San Diego, CA, p 294-330

Lawton RP, Scherer M (1996) Semi-annual report number 49. In: Anderson RD (ed) Marine ecology studies: related to operation of Pilgrim Station. Boston Edison Company, Plymouth, MA

Levin PS (1991) Effects of microhabitat on recruitment variation in a Gulf of Maine reef fish. Mar Ecol Prog Ser 75 : 183-189

Levin PS (1993) Habitat structure, conspecific presence, and spatial variation in the recruitment of a temperate reef fish. Oecologia 94:176-185

Levin PS (1994a) Fine-scale temporal variation in recruitment of a temperate demersal fish: the importance of settlement versus post-settlement loss. Oecologia 96:168-178

Levin PS (1994b) Small-scale recruitment variation in a temperate fish: the roles of macroalgae and food supply. Environ Biol Fishes 89:77-88

Levin PS (1996) Recruitment in a temperate demersal fish: Does larval supply matter? Limnol Oceanogr 41:672-679

Levin PS, Chiasson W, Green JM (1997) Geographic differences in recruitment and population structure of a temperate reef fish. Mar Ecol Prog Ser 161:23-35

Meekan MG, Milicich, MJ, Doherty PJ (1993) Larval production drives temporal patterns of larval supply and recruitment of a coral reef damselfish. Mar Ecol Prog Ser 93: $217-225$

Mercer IRG, Barker DE, Khan RA (1997) Stress-related changes in cunner, Tautogolabrus adspersus, living near a paper mill. Bull Environ Contam Toxicol 58:442-447

Milicich MJ, Meekan MG, Doherty PJ (1992) Larval supply: a good predictor of recruitment of three species of reef fish (Pomacentridae). Mar Ecol Prog Ser 86:153-166

Olla BL, Bejda AL, Martin AJ (1975) Activity, movements and feeding behavior of the cunner, Tautogolabrus adspersus and comparison of food habits with young tautog, Tautoga onitis, off Long Island, New York. Fish Bull 73:895-900

Pottle RA, Green JM (1979a) Field observations on the reproductive behavior of the cunner, Tautogolabrus adspersus (Walbaum), in Newfoundland. Can J Zool 57:247-256

Pottle RA, Green JM (1979b) Territorial behavior of the north temperate labrid, Tautogolabrus adspersus. Can J Zool 57: 2337-2347

Robertson DR, Schober UM, Brawn JD (1993) Comparative variation in spawning output and juvenile recruitment of some Caribbean reef fishes. Mar Ecol Prog Ser 94:105-113

Sale PF (1978) Coexistence of coral reef fishes-a lottery for living space. Environ Biol Fishes 3:85-102

Sale PF (1991) Introduction. In: Sale PF (ed) The ecology of fishes on coral reefs. Academic Press, San Diego, CA, p 3-8

Schroeter SC, Dixon JD, Kastendiek DJ, Smith RO (1993) Detecting the ecological effects of environmental impacts: a case study of kelp forest invertebrates. Ecol Appl 3: 331-350

Shulman MJ (1984) Resource limitation and recruitment patterns in a coral reef fish assemblage. J Exp Mar Biol Ecol 74:85-109

Shulman MJ (1985) Recruitment of coral reef fishes: effects of distribution of predators and shelter. Ecology 66: 1056-1066

Shulman MJ, Ogden JC (1987) What controls tropical reef fish populations: recruitment or benthic mortality? An example in the Caribbean reef fish Haemulon flavolineatum. Mar Ecol Prog Ser 39:233-242

Smith CL (1978) Coral reef fish communities: a compromise view. Environ Biol Fishes 3:109-128

Sokal RR, Rohlf FJ (1981) Biometry: the principles and practice of statistics in biological research, 2nd edn. WH Freeman \& Co, New York, p 403

Steele MA (1997) The relative importance of processes affecting recruitment of two temperate reef fishes. Ecology 78 : 129-145

Steele MA (1999) Effects of shelter and predators on reef fishes. J Exp Mar Biol Ecol 233:65-79

Stimson JS (1990) Density dependent recruitment in the reef fish Chaetodon miliaris. Environ Biol Fishes 29:1-13

Tupper M (1994) Settlement and post-settlement processes in the population regulation of a temperate reef fish: the role of energy. PhD thesis, Dalhousie University, Halifax

Tupper M, Boutilier RG (1995a) Effects of conspecific density on settlement, growth and post-settlement survival of a temperate reef fish. J Exp Mar Biol Ecol 191:209-222

Tupper M, Boutilier RG (1995b) Effects of habitat on settlement, growth, and postsettlement survival of Atlantic cod (Gadus morhua). Can J Aquat Sci 52:1834-1841

Tupper M, Boutilier RG (1997) Effects of habitat on settlement, growth, predation risk and survival of a temperate reef fish. Mar Ecol Prog Ser 151:225-236

Victor BC (1983) Recruitment and population dynamics of a coral reef fish. Science 219:419-420

Victor BC (1986) Larval settlement and juvenile mortality in a recruitment-limited coral reef fish population. Ecol Monogr 56:145-160

von Ende CN (1993) Repeated-measures analysis: growth and other time-dependent measures. In: Scheiner SM, Gurevitch J (eds) Design and analysis of ecological experiments. Chapman Hall, New York, p 113-137 
Walton DG, Penrose WR, Green JM (1978) The petroleuminducible mixed function oxidase of cunner (Tautogolabrus adspersus Walbaum 1792): some characteristics relevant to hydrocarbon monitoring. J Fish Res Board Can 35:1547-1552

Walton JM, Bartoo NW (1976) Flatfish densities determined

Editorial responsibility: Richard Haedrich (Contributing Editor), St. John's, Newfoundland, Canada with a diver-operated flounder sampler. J Fish Res Board Can 33:2834-2836

Williams UP, Kiceniuk JW (1987) Feeding reduction and recovery in cunner Tautogolabrus adspersus following exposure to crude oil. Bull Environ Contam Toxicol 38:1044-1048

Submitted: July 26, 2000; Accepted: August 12, 2001

Proofs received from author(s): January 21, 2002 